\title{
Svar til tre kritikere
}

\author{
fra Kaj Thaning
}

\section{HARRY ARONSON}

»Kampen fortsætter«, slutter Aronson sin kritik af min bog (Gr.St. I964) - og jeg tilslutter mig gerne. Vi må videre i forsøget på at tolke Grundtvig rigtigt. Men der er i vort tilfælde ikke blot tale om to forskellige Grundtvigtolkninger over for hinanden, men om to måder at nå frem på. For Aronson drejer det sig i første række om at hævde, at både den opgave, jeg har stillet mig, og min fremgangsmåde er videnskabeligt håbløse. Forsøget på at nå frem til Grundtvigs »inre jag « er et »overambitiøst« og faktisk umuligt forehavende. Min benyttelse af kilderne er desuden rent subjektiv (her i betydningen vilkårlig) og har ført til, at jeg kun har fundet mig selv i Grundtvigs forfatterskab. Jeg har påtaget mig en opgave, som ikke er videnskabeligt muligt, fordi det er metodisk umuligt at verificere et menneskes inderste kamp med sig selv. Resultatet bliver derfor: en ren konstruktion (s. 88).

Men Aronson har allerede misforstået mit mål. Det er ikke Grundtvigs indre liv og i denne psykologiske forstand heller ikke hans »inderste kamp«, jeg har villet kortlægge. Aronson vilde have ret, hvis jeg havde opfattet min opgave psykologisk dissekerende. Han har før bebrejdet mig, at jeg ikke har gjort rede for, hvilke psykologiske teorier jeg har anvendt under udforskningen af Grundtvigs indre liv. Men hverken det eller det naturvidenskabeligt orienterede verificationsbegreb, han forlanger anvendt, har jeg interesseret mig for-derimod for Grundtvigs saglige opgør med sig selv, sådan som det kan aflæses i de foreliggende tekster. Når disse under det fremadskridende selvopgør præges af uklarhed og indre selvmodsigelse, har jeg søgt at tolke dem ud fra de indbyrdes modstridende tanker, som forfatterskabet viste havde greb i ham (Irenæusteologien, naturfilosofien, bodskristendommen, Luthers forkyndelse etc.). Og ud fra konstateringen af et samtidigt skred på en lang række områder (menneskesyn, historiesyn, kirkesyn, prædiken, salmedigtning, videnskab, oplysning, politik etc.) - altså et livssyns kæntring - har jeg sluttet mig til et generalopgør efter lang tids kamp for klarhed og har 
søgt frem mod det springende punkt i dette opgør. Det er alene teksterne, der giver dette resultat.

Ganske naturligt kan det ikke verificeres, som en naturvidenskabsmand muligvis kan verificere sit forskningsresultat - det kan ikke »bevises eller modbevises«, sådan som Aronson forlanger det. Men det kan sandsynliggøres. Når det er det hele, siger Aronson, er det ikke let at diskutere resultatet. Men det er da netop kun i dette tilfælde, diskussion er mulig! Ikke hvis der er tale om bevis.

Man kan ved hjælp af mit resultat få en nøgle til at forstå mange ellers vanskeligt opfattelige bestræbelser under udformningen af det følgende forfatterskab (jfr. mit efterfølgende svar til Michelsen), ligesom til at analysere megen uklarhed i det, Grundtvig skrev, for klarheden kom. Ja, det nye, der er på vej frem, kan tit netop kun spores i bisætningen, selvom det endnu ikke præger hovedsætningen. Man kan virkelig ved »nærlæsning« komme på spor af, hvad der var Grundtvigs egentlige problem. Ikke hans »indre jeg«, men hans problem og hans tumlen med det. Her kræves ikke psykologiske teorier, men der kræves en vis føling med problemet for at fatte dets betydning. Forsåvidt visse »subjektive« forudsætninger. Men skal man ikke også have sådanne for at bedømme Aronsons resultat? Hvad han vil, er at fremlokke »et klart billede« af det undersøgte materiale (disp. s. 12). Men for hvor mange vil hans billede være klart? Og hans egen opfattelse af det (logisk) klare har netop ofte ledt ham selv på vildspor (f. e. hvad betydningen af den irenæiske forførelsestanke angår, og hvad adskillelsen af den folkelige og den kirkelige grundtvigianisme angår: den må skyldes en indre svaghed i Grundtvigs »system《. Jfr. min bog s. 765 og 749 f).

Og selvom man finder, at billedet er klart, kan det jo udmærket være forkert. Klarhedens »verification« er svigefuld. Den er nemlig (subjektivt) bestemt af, hvem man er. Hvad en finder klart, finder en anden uklart. Vel at mærke, når det drejer sig om livssyn. Med matematik og logik forholder det sig anderledes. Men hvad vilde mon f. e. en logisk empirist stille op med Aronsons bog? Den kræver personlige forudsætninger hos sin læser såvel som min.

Jeg har selv tilstræbt klarhed. F. e. når jeg har ment at måtte konstatere uklarhed og indre selvmodsigelse hos Grundtvig. Ordet »indre« refererer til hans tankegang. Vi har jo kun med Grundtvigs tanker at gøre, ikke med hans ukontrollable sjælelige dybder eller hans indre sekretion - selvom man, ud fra en i tid afgrænset afvigelse fra hans sædvanlige tankegang kan nødes til antage en opblussen af den sindssygdom, som man ved, han havde lidt under kort tid $\mathrm{i}$ forvejen. Havde han 
gennemgående været uklar i tanken, var der ingen grund til at forklare besynderlige tekster ud fra den indre sekretion, eller hvad der nu er årsagen til sindssygdom. I det tilfælde, jeg tænker på, foreligger bl. a. en tekst (en vennemødetale i i 868), som jeg finder stridende mod Grundtvigs sædvanlige tankegang, men som Aronson finder »interessant« (min bog s. 757). Den støtter da også hans tolkning af Grundtvigs tankeverden. Men eksemplet viser, hvor forskelligt vi opfatter den indre sammenhæng i den - og hvad »klarhed « altså vil sige for os.

Når jeg så stærkt har vendt mig imod Aronsons Grundtvigtolkning, skyldes det selvfølgelig kun uvilje mod det (lad mig bruge hans eget udtryk) overambitiøse ved denne form for teologisk videnskab, denne kraftsystematik, der uden hensyn til Grundtvigs kamp får ham lagt fast i et teologisk helhedssyn, han selv gjorde sig fri af. Man mener at kunne anvende et videnskabeligt objektivitetsbegreb på analysen af forfatterskabet uden mindste erkendelse af dets afhængighed af den, der bruger det. I stedet for al den metodesnak burde pladsen derfor være brugt til at gå til teksterne for at få konstateret, hvad de siger, og hvem af os der tolker dem nøjagtigt. I min bog går jeg hele tiden til dem og bygger min Aronson-kritik op på hans fejltolkninger. Så at sige alle peger de ind mod samme skavank $\mathrm{i}$ hans helhedsopfattelse. Kun ganske få af mine indvendinger har han siden taget op. Derimod har han - sidst på et forskermøde i august 1964 - forelagt en lang række tekster, som han mente modbeviste min opfattelse (jfr. Gr.St. s. 8o). Trods 7 timers drøftelse lykkedes det ikke at få nogen af dem til at tale min opfattelse imod (diskussionen om de af Aronson påny anførte genoptages i det flg., så enhver kan dømme i sagen). Men det, der forbavsede mig, var at Aronson mente, de gjorde det! Han har i virkeligheden ikke fået fat $\mathrm{i}$ min tese og min tolkning.

Vore opfattelser er modsatte, har jeg hævdet. Hvad jeg tænker på, står i slutningen af min gennemgang af hans bog (s. 770): hans fejltolkninger kommer »af samsynet, af den grundlæggende misforståelse at applicere den kristne skabelsestanke på Grundtvigs profane forfatterskab og derved få det ind i kirken, underordnet det trinitariske »system《, hvorved Grundtvig bliver »en enastående gestalt i i8oo-talets kyrkohistorie« gennem sin evne til »att samla mänskligt och kristet i en sluten åskådning «. Forholdet er for mig at se det omvendte, at det er hans adskillelse af det menneskelige og det kristelige, der er enestående.« Her står to (selvfølgelig subjektivt bestemte) vurderinger over for hinanden.

Aronson misforstår imidlertid min opfattelse, idet han her bruger or- 
det 》isolere« (disp. s. 8I note 4) i stedet for adskille. Grundtvig siger selv, at der er tale om en adskillelse for tanken (min bog s. 638). Ved isolation forstår Aronson, at der bliver tale om to stykker, som intet har med hinanden at gøre. Ud fra denne tankegang er det, han har samlet de citater sammen, der skulde modbevise mit syn. Men for det første har jeg selv anvendt ca. halvdelen af dette stof til støtte for mit eget syn, og for det andet støtter ingen af citaterne Aronsons påstand, at det menneskelige og det kristelige »betinger《 hinanden hos Grundtvig. Nej, det menneskelige er forudsætningen for det kristelige. Den prædiken fra 1832, som jeg bruger til netop at vise omslaget hos Grundtvig på dette punkt (»til det naturlige maa vi derfor tilbage ... for paa en ordenlig og levende Vej at komme til det aandelige, som Herren skjænker ...« (s. 533)), vil han benytte mod mig! Det er helt mærkværdigt, at Aronson kan tale om isolation, når adskillelsen mellem det menneskelige og det kristelige bl. a. kommer til at betyde, at det menneskelige er forudsætningen for, at evangeliet overhovedet kan få mening: »det aandelige« skal ikke længere være os »noget fremmed« (s. 533). Gnosticismen er nemlig nu den store modstander. Også i min kritik af Aronson har jeg understreget (ikke som en indrømmelse, Gr.St. s. 86), at hans »samsyn « er på sin plads, når det gælder Grundtvigs kristne forkyndelse (s. 754). Her finder Gud og menneske hinanden i Kristus. Men kristologien hører hjemme i kirken (og Irenæusteologien strider derfor ikke mod min tese!). I kirken taler Grundtvig troens tale, ikke uden for den.

Aronson har ret i, at den internt teologiske opgave ikke er løst af mig (Gr.St. s. 87). Jeg har nemlig slet ikke sat mig som opgave at analysere Grundtvigs kristne forkyndelse ud fra dens indre struktur. Og hvis Aronson selv havde begrænset sig til denne opgave, så vilde der være kommet en i hvert fald meget bedre bog ud af hans arbejde. Men han har villet se hele forfatterskabet ud fra kristologien. Han går som nævnt ud fra treenighedslæren (jfr. trosbekendelsen), og ud fra I. trosartikel mener han at kunne nå frem til et samsyn af menneskeligt og kristeligt. Adskillelsesmotivet nævnes, men spiller ingen virkelig rolle hos ham. På et afgørende sted hos Grundtvig udelades det ligefrem af Aronson ( $\min$ bog s. 749 f). Han forstår det simpelthen ikke. Det er derfor ikke med hensigt, han har udeladt noget (det er kun mig, der iflg. Aronson gør noget sådant). Ikke desto mindre er vi her ved det »enestående«. På baggrund af adskillelsen kan Grundtvig i kirken på »en ordenlig og levende Vej« komme til det guddommelige, som vi »højlig trænge til« - for så i 
verden at gå frit løs på de krævende spørgsmål, nu uden en kristen norm som forudsætning.

Jeg er ikke fortrolig med Aronsons udtryk »pluralisme« (s. 8I), men er mistænksom over for dets relevans i tilfældet Grundtvigs kultursyn. I hvert fald forstår jeg ikke, at dette ikke skulde hænge på det nøjeste sammen med hans »faktiska åskådning « (s. 82). Netop gennem denne er Grundtvig jo blevet frigjort fra kristelige normer til i stedet for $\mathrm{i}$ menneskeslægtens historie at søge de normer, der må gælde for f. e. en nordisk kultur - alt under det antignostiske motto »for menneskelivets skyld«. Grundtvigs stillingtagen er »af praktisk art«, men han har absolut et synspunkt derfor, som hænger nøje sammen med hans livssyn: »enten det er Tysken eller Latinen, jeg bekæmper, og enten det er Modersmaalet $i$ Folkemunde, eller Friheden eller Christendommen, jeg priser og ophøier, saa er det bestandig for Livets, for Menneskelivets Skyld. ..« (s. 642). En kulturel pluralisme er iflg. Aronson en måde, hvorpå man kommer til rette med faktisk foreliggende uligheder og modsigelser i en kulturkreds. Men iflg. denne definition synes Grundtvig at have været alt andet end kulturel pluralist. Han kom jo ikke til rette med kulturmodsigelserne, men gik løs på spørgsmålene ud fra sit markante kultursyn. At det ikke var et kristent kultursyn, kan ikke betyde, at pluralismen så er alternativet dertil. Men Aronson kan åbenbart ikke tænke sig andre muligheder.

For at få fat i Grundtvigs kultursyn er jeg ikke gået ud fra hans indre liv, men ud fra hans problem og dets løsning i 1832 og de muligheder, der derigennem åbnede sig for ham. Men altså netop fra hans personlige »åskådning « (s. 8I), der har medført hans accept af verden, som den foreligger. Jeg må ikke sammenblande de to ting, siger Aronson. Jamen, det er jo hans livssyn, der tilsiger ham at acceptere menneskelivet, efter at han nu har fået øje for det. Før har han villet omskabe det. Men hans omvendelse betød et nyt forhold til livet og arbejdsopgaverne. Netop »Mands Minde« (Gr.St. s. 8I f) bærer vidnesbyrd om denne omvendelse og den deraf følgende adskillelse af tingene - jfr. f. e. hans nye forhold til spørgsmålet kristendom og politik.

Mærkeligt, at Aronson ikke heri kan finde et »systematisk-teologisk « aspekt. Han hævder, at jeg har forladt dette og er blevet stadig mere »ideologisk « i min fremstilling - jeg beskæftiger mig mest med kultursyn og kulturkamp. Ja, jeg følger Grundtvigs forfatterskab fra 1832 fremefter, men belyser så i 3 . del omslaget i hans kristendomssyn og dets forhold til de menneskelige og folkelige forudsætninger. Men har 
forholdet mellem antropologi og teologi ikke systematisk-teologisk interesse? Jo, vil Aronson vel hævde, inden for et teologisk helhedssyn. Men det at Grundtvig har fået øje for menneskelivet bortset fra tro og teologi, betyder, at den sekulariserede historisk-poetiske oplysning om livet foruden at have sin mening i sig selv - nu er forudsæetning for tro og teologi. Det er Grundtvigs opdagelse af gnosticismen i den gamle lutherdom, der finder udtryk i dette notabene til al teologi, til ethvert kristendomssyn. Og til Aronsons overraskelse (min bog s. 762) henter Grundtvig sit menneskesyn fra danskheden, hverken fra Jødeland eller Himmerig.

Vi er her ved den artikel »Moses og Jesus«, som Aronson henviser til som eksempel på, hvor forskelligt vi tolker (s. 94). Her bliver Paulus' udtryk »tugtemester« (om loven) til Grundtvigs »skolemester«, fordi han sætter sin oplysningstanke ind i stedet for lovtanken som forudsætning for evangeliet. Ikke desto mindre taler Aronson her og mange andre steder om »skapelsens lag «, til trods for at dette synspunkt er tvangspåført Grundtvig. I hans parafrase sker det to gange, at »loven« indføres, uden at teksten stemmer dermed: Moses' opdragelse er en afsløring af menneskets situation under loven, siger Aronson (disp. s. 23 I f) mens Grundtvig her netop afløser tugtemesteren med »Skolemesteren for al Verden«. Den forberedelse, som forsagelsen og troen forudsætter, skildres derefter som »en Oplysning, man frit benytter sig af, som man kan og vil «. Lovpræget er således forsvundet fra Moses! Ikke desto mindre kommenterer Aronson: »Lagen skal således förkunnas som en troværdig oplysning, som passar til vederbörandes situation og tillägnelsesförmåga« (disp. s. 232). Unægtelig får loven således »en annan karaktär än i paulinsk-luthersk teologi«. Men var det ikke bedre at holde sig til Grundtvigs eget udtryk »oplysning « end at fastholde den klassiske teologis lovbegreb? Uden lyset fra skabelses- og syndefaldsberetningen i Genesis kan man ikke - siger Grundtvig - tænke sig nogen »christelig Væxt og Udvikling « (foran det sidste ord indføjer Aronson ordet »etisk « i sin parafrase) - men nok kristen tro! Hvor vil Grundtvig hen? Som når han tilføjer, at det holder hårdt nok, at vi ved hjælp af »Loven og Profeterne« kommer til at forstå den 3. trosartikels tale om ånden og troen ret gennem deres oplysning om ånd og hellighed?

Han vil hen til sin egen opdagelse! »Folk, som ikke selv er Jøder, har ondt ved at forstaa Moses og endnu vanskeligere ved at fæste Tro til den 
oplysning, han giver enten om Skabelsen, Syndefaldet eller om den Guds-Lov, der synes at føre meer Forbandelse end Velsignelse med sig, saa der er en egen Forberedelse, ethvert Hedning-Folk og enhver af os, som hører til dem, behøver til Oplysning om os selv og vor egen Deel af Menneskeligheden, førend den Mosaiske og Prophetiske Oplysning kan gaa lyslevende ind i os«. Men det formindsker lige så lidt vor trang til oplysning af Moses, som det formindsker vor trang til oplivelse af Jesus, at vi forud må være levende mennesker på vor vis. Det er nemlig en gammel sandhed, »at man, for at see noget, selv ved det klareste Lys, baade maa have Øine at see med og have lært at lukke sine Øine op«. Uden på dansk at have fået at vide, »hvad Ordene Gud, Menneske, Aand, Sjocl, Sandhed, Løgn, Lov, Synd, Retfardighed, Godhed, Naade, Barmhjertighed, Fred, Tro, Haab og Kiarlighed, med mange andre Ord om de indvortes og usynlige Ting, paa deres Modersmaal vil sige«, vilde både Moses og Jesus tale forgæves. Bibelen kan ikke give nogen liv, men trænger selv til »et levende Lys« for at komme til at stå for os som vort guddommelige oplysningsredskab.

Aronson hævder, at det er overflødigt at se denne tekst ud fra drejningen i 1832. Men den kan ikke forstås uden. De ro bud er nu afløst af oplysningen, og loven er nu kærlighedsbuddet, denne »Kiærlighedens aandelige og hjertelige, almindelige og uforanderlige Grundlov, som Christendommen forudsatter og lover at opfylde med den Kiærlighed, som er Lovens Fylde.« Her tænker Grundtvig etisk, men ikke når han taler historisk om Gudsloven i Israel (der »synes« at føre mere forbandelse end velsignelse med sig), og heller ikke, når han taler om »vor egen Deel af Menneskeligheden«, som den oplyses gennem modersmålets ord. Ordet »lov« gemmer sig her mellem en lang række andre ord, men er kommet med, fordi der her tales om forberedelsen til at forstå alle de bibelske ord. I lignende opregninger af grundord for den menneskelige oplysning forekommer det ellers ikke. Og netop fordi man frit benytter sig af denne oplysning, som man kan og vil, er der ikke tale om nogen »lag«. Men uden fri, hjertelig, menneskelig oplysning hænger talen om kærlighedens grundlov og om evangeliet $i$ luften. I anledning af Grundtvigs frie oplysning nødes Aronson til at tale om »en viss paradoxalitet«, fordi han opfatter den som lov (disp. s. 24I). Men dette fremmedord passer ikke på Grundtvig.

Det karakteristiske for denne tekst er - trods Aronson - at det etiske perspektiv undervejs forsvinder, og »oplysningen« træder ind i stedet for loven i paulinsk forstand. Moses bliver skolemester. Aronson finder 
derimod i artiklen »starka uttryck för Grundtvigs tolkning af lagen såsom en skapelsens lag. Det historisk-poetiska bär i sig en sådan lag« (s. 94). Dog siger Grundtvig andetsteds: »Al Livsoplysning er mild og blid«. Der er altså noget, der ikke stemmer. Menneskeligheden som »et levende Lys k kan ikke tolkes ved hjælp af ordet lov. Teksten sprænger netop »de klassiska teologiska frågeställninger« (s. 95). Og det er det, der er det karakteristiske ved den. Etikken er derimod at finde i kærlighedsbuddet, som Aronson ikke giver den plads, det skal have.

Grundtvig vil - gennem danske ord som de nævnte - oplyse »de grundmenneskelige Livs-Forhold « forud for al teologi, men disse formuleringer kalder Aronson »en bärande tankeskapelse i Grundtvigs teologi, som man mycket väl kan karakterisera med ordningsföljden lag-evangelium, eller mere grundtvigskt: mänskligt och kristet« (s. 94). Det synes blot at være et terminologisk spørgsmål, hvad man skal sige. Men dermed er det særligt grundtvigske tabt under bordet. Hans oplysning er blevet rykket ind i teologien. Adskillelsen er ikke blevet tolket. Det forholder sig på lignende måde, når talen er om relationen mellem kærlighedens gerninger, som har sin kilde i kirken, og de gerninger, som gøres ude i verden uafhængigt af evangelieforkyndelsen (disp. s. 245). Aronson hævder, at Grundtvig her betoner det fælles. Kirkens menneskelighed er en hovedtanke hos ham, som kommer tydeligt frem også i den etiske sammenhæng. En sand kristen kan »möta och bli mottagen av en medmänniska som en broder«. Men jeg kan ikke erindre nogen steder hos Grundtvig, der støtter dette, og Aronson anfører da heller ingen. I denne ugrundtvigske tankegang ender hans forsøg på at afdække Grundtvigs etik. Når det hævdes, at den kristne og det ikke-kristne medmenneske er forenet i kampen for livet, fordi »i Kristus kan allt sant mänskligt mötas«, så er dette kristologiske synspunkt en for Grundtvig fremmed tankegang. Hvad kampen for livet angår, tænker Grundtvig ikke ud fra kirkens Kristus. Her tænker han menneskeligt, ikke kristeligt. Og der er medmennesker, der ikke er indstillet på denne kamp. Det kommer ikke frem hos Aronson. Uden for kirken, i kulturkampen nivelleres modsætningerne hos ham ( $\min$ bog s. 749).

Om Grundtvig og etikken vil jeg afsluttende sige: det er påfaldende at stå over for en tænker, hvis filosofi er så kamp- og modsætningsbestemt - og dog så umedgørlig i etisk henseende. Det er et beundringsværdigt forsøg, Aronson har gjort på at få hans tanker bundet etisk sammen. Men hans udgangspunkt er, at det $m a ̊$ kunne lade sig gøre! Forsøget har (mod Aronsons metodiske grundprincip) ikke sin anledning i selve forfatterskabets art. 
Det er sandt, at Grundtvigs skabelsessyn langt fra er tomt, »tömd på krafter« (disp. s. 225). Det er i høj grad kamppræget. Men selv om der i Grundtvigs anskuelse foreligger »något til handling inciterande element« (s. 236), er der dog endnu ikke dermed tale om et etisk perspektiv. Og slående er det, at når Grundtvig vil nævne de modsætninger, som dur til »at oplyse Menneske-Livet heelt og holdent, som det er« (s. 240) - så nævner han lys og mørke, liv og død og sandhed og løgn, men $i k k e$ den etiske modsætning godt og ondt!

Grundtvig må som antropologisk filosof skildres ud fra sine egne forudsætninger, hvoriblandt opgøret med hans egen tidligere etiske tankegang. Og menneskets »fördömelse« skal ikke begrundes ud fra en »skapelsens lag« (s. 24I), men ud fra kærlighedsbuddet, jfr. hans prædikener og salmer. Grundtvig er først historiker, digter og filosof (dansk »skolemester ), og hans historisk-poetiske syn er ikke etisk bestemt. Men så er han derefter kristen forkynder og kender som sådan udmærket forskel på godt og ondt, kærlighed og selvkærlighed. Og da får også de tre tidligere nævnte modsætninger deres kristne betydning - jfr. alle de før citerede grundord, som har deres danske betydning, før de får deres kristne mening, og uden at der er nogen glidning fra antropologi til teologi ( $\min$ bog s. 756). Oplevelsen af sandheden om det menneskelige »fører« således ikke til Kristus (s. 242 - jfr. dog min anmærkning om Grundtvigs tvangstanker s. 770 ff). »Adskillelsen« holder det menneskelige på plads.

Lige så lidt som jeg selv internt har skildret Grundtvigs teologi, har jeg forsøgt at udfolde hans danske, menneskelige og i høj grad modsætningsbestemte filosofi systematisk. Det kan imidlertid gøres og burde gøres - men ud fra dens egne forudsætninger, ikke ud fra indførte teologiske eller etiske synspunkter.

Derefter til Grundtvigs skolesyn! I sin disputats (»Skolen for livet« s. 344) har Bugge hævdet, at skoleskrifterne kun i begrænset omfang giver Aronson ret. Skabelsestanken er kun fremme »så få steder, at det herudfra vil være uberettiget at gøre denne tanke til det bærende synspunkt.« Når Bugge tilføjer, at Aronson har ret i, at »der består en relevans imellem Grundtvigs teologi og hans pædagogik, men næppe i sin opfattelse af, hvori relevansen består«, så har Bugge ret i, at skolen bidrager til »forklaring « af det timelige menneskeliv. Men denne »forklaring er igen forudsætning for den kristne eskatologi, så at det menneskelige også her er forudsætning for det kristelige (min bog s. 699 f). 
Deri alene består relevansen. - For resten er det hos Bugge selvmodsigende, at han standser sin redegørelse i 1847, fordi Grundtvigs pædagogiske tanker da har fundet deres blivende udformning (s. 19), når han dog har indtryk af, at Aronson får mere ret i den senere fase af forfatterskabet (s. 344). Forholdet mellem teologi og pædagogik er jo vigtigt for Bugge.

Først må jeg sige, at et enkelt sted hos Aronson er mig helt ubegribeligt - også ud fra hans egen tankegang. Efter at have nævnt, at Grundtvig tit anfører ordet om, at »Naturen gaar over Optugtelsen«, fortsætter Aronson: »Den syn på uppfostran som därigenom kommer till uttryck, är fullt konform med synen på lagen, som hos Grundtvig blir liktydigt med skapelsens lag« (s. 266). Ja, Grundtvig glæder sig over, at naturen er gået over optugtelsen hos ham selv (Danskeren IV s. 338), men der er overhovedet ingen forbindelse med nogen skabelsens lov, hverken når han taler om optugtelsen eller om naturen (og udtrykket »Naturens Orden« er bevidst sekulariseret og ikke etisk af indhold).

Hvad nu skolesynet angår, anklager Aronson mig for »rene förtiganden« i Grundtvigteksterne og for at have undertrykt hans egne teksthenvisninger. Det er en alvorlig anklage. Det er rigtigt, at jeg forkortet har gengivet hans ord om, at Grundtvig i den menneskelige mangfoldighed finder et orienteringspunkt i skabelsestanken. Skolen kan Grundtvig derfor se som en virksomhed »for Menneske-Livet i Guds Billede« (Gr.St. s. 92). Jeg skriver, at Aronson må helt hen til en begravelsestale i »Kirkelige Lejlighedstaler« for at finde bevis for, at skolen er til »for Menneskelivet i Guds billede« (kristeligt forstået) (s. 750). Aronson vil holde på, at han selv har set tanken fra begravelsestalen som »en delaspekt«, hvorimod jeg har gengivet synspunktet som totalt. Men efter at være gået videre fra Grundtvigcitatet konkluderer Aronson på næste side (s. 265) : »Tanken på skapelsen till Guds avbild, människans konkreta liv och Kristi mänskliga natur blir därmed den idemässiga basen varpå skoltankarna bygges upp. Därmed indordnas Grundtvigs skolprogram i hela hans åskådning«. Denne konklusion viser, at jeg alligevel må have forstået Aronsons syn rigtigt.

Hvad begravelsestalen angår, har jeg (s. 774 note Io) oplyst, at den afdøde, Grundtvigs medhjælper pastor Boisen, var lærer ved Caroline Amalies asylskole, hvor børnene blev »folkeligt og kristeligt oplyst«. Der er derfor her ikke tale om det, Grundtvig kalder »Skolen«. Vennemødetalen 1866, som Aronson citerer for at vise, hvordan ordets begreb fører Grundtvig videre ud over det skabtes verden til troen og genoprettel- 
sens verden, har jeg også kommenteret (s. 753). Henvisningen til denne tale underbygger ikke Aronsons påstand (disp. s. 264). Bl. a. tales der her om Jesus som menneskelig læremester og ikke som frelseren.

Men nu til Marielysttalerne! Her slås det fast (s. 76), at kristendommen er »slet ingen Skolesag « (selvom man altså drev både kristelig og folkelig oplysning i asylskolen!). Men det betyder selvfølgelig ikke, at Grundtvig ikke begynder på sit højskoleværk »i Vorherres Navn« (s. 7, jfr. højskolesangen) og »med Guds Hjælp« (s. 14). Nu har jeg, som Aronson anfører (Gr.St. s. 92), ikke hævdet, at skaberen ikke er fremme i Marielysttalerne. Men jeg har slet ikke tænkt på dem, men på forholdet mellem skoleskrifterne og f. e. verdenshistorien (foruden begravelsestalen, min bog s. 750). Der er altså ikke på »listig « vis tale om nogen fortielse m. h. t. de steder i Marielysttalerne, som Aronson henviser til. Alle de ud fra mit synspunkt relevante steder har jeg kommenteret. Men han mener altså, at flere steder må være det, selvom han egentlig kun motiverer sine sidehenvisninger (s. 93) med, at skaberen i hvert fald nævnes i talerne.

I den betydning, hvori han selv lægger vægt på den skabertanke, der er hentet fra trosbekendelsen, kommer dog ingen af de anførte steder i betragtning. Forsynstanken har ingen af os lagt vægt på (jfr. s. 5, 7, 9, I 4, 28, 6o, 75). Udtalelser som »Vorherre, som alt godt kommer fra og som giver Væxt《 (s. 8) og »Menneske-Livet, som vi får af Vorherre og vore Forældre« (s. 18), har paralleller i højskoleskrifterne (min bog s. 389 og 4 or, hvor jeg kommenterer: »Selve skabelsestanken har i højskoleskrifterne et noget traditionelt præg «).

Hvad der skiller os, er min påstand, at Grundtvig som skolemand, historiker o. s. v. sekulariserer skabertroen, idet han er sig bevidst at have skabertanken tilfælles med ikke-kristne. Det er da også tilfældet i Marielysttalerne. Når han taler om »denne forunderlige Skabning af Støv og Muld, der ... bærer Lyset usynlig i sig« (s. Io), om oplysning af »det forunderlige Menneske-Liv i Guds Billede« (s. 52), om ordet på tungen, der opløfter »Mennesket skabt i Guds Billede, himmelhøit over alt det umalende« (s. 55) og om »et ganske eget, forunderlig Slags levende Skabninger i Guds Billede《 (s. 6I ) - så er han sig bevidst, at dette ikke er en speciel kristen tale. Tanken er ikke knyttet til trosbekendelsen. Det fremgår netop af selve Marielysttalerne. I 1865 taler han - foruden om forfædrenes tro på »et guddommeligt Forsyn, som de i den hedenske Tid kaldte Nornerne - om den »Oplysning om Gud og Menneske«, som »de store Selv-Tænkere enten finde hos sig selv eller udpine af den 
umælende Natur«. Den skal afvises af Nordens folk, når de kommer til at »tænke naturlig«. I Norden er al oplysning nemlig historisk (s. 75). Altså skal det sande og levende menneskesyn ikke uddrages af kristendommen, men hentes frem ad historisk vej (den tanke, der har overrasket Aronson). Svarende hertil henviser Grundtvig i 1866 til grækernes og nordboernes følelse af at være »i Slægt med Guddommen«. Men nordboerne fandt dog »mere af Guds-Billedet hos sig end andre Hedninger« (s. 8o).

Selvom udtrykket »Menneske-Livet i Guds Billede« er bibelsk, er sagen det altså ikke. Der er skelnet mellem talen i kirken og talen i skolen, hvad de endnu ikke nævnte af Aronsons henvisninger direkte handler om. I) I kirken taler Grundtvig om menneskets forhold til sin Gud og skaber, på rigsdagen om borgerlige forhold og på Marielyst om menneskets forhold til sig selv og sit folk (s. I I). 2) Der er forskel på brugen af Jesu lignelser (i kirken) og de hedenske forfædres lignelser (til oplysning af det danske folk efter vore egne folkelige vilkår, hvad der er forudsætning for at komme til Vorherre, s. 25). 3) Ordet er det eneste middel til at oplyse mennesket i sine tre grundforhold: til det guddommelige i kirken, til det borgerlige i staten og til sig selv i sin åndelige og hjertelige fylde i skolen (s. 89, 1867 ).

Dermed har jeg kommenteret alle de af Aronson anførte steder (undtagen det »folkeligt-etiske« sted s. I $7 \mathrm{f}$ - som man kunde kalde det, og som Aronson selv dog ikke kan bruge til noget). Han påstår, at det at læse Marielysttalerne med min tese »som slagruta är överhuvudtaget inte möjligt« (s. 94). Men det forholder sig lige omvendt. Når jeg i min bog ikke har taget de af Aronson nu betonede steder med, er det simpelthen, fordi de af sig selv stemmer ganske overens med min tese: at Grundtvig sondrer skarpt mellem kirke og skole, at han i skolen ikke bygger på kristeligt fundament og heller ikke gør det, når han i skolen taler om mennesket skabt i Guds billede. De problematiske steder fra Grundtvigs allersidste år har jeg kommenteret i min bog (s. $73^{8} \mathrm{ff}$ ).

I denne sidste anledning må jeg gøre opmærksom på, at det er en misforståelse, at min fremstilling er skrevet sådan, at læseren skal tro, »at det blir svårt för tesen först $\mathrm{i}$ och med $\mathrm{I} 864$ « (s. 94). For heller ikke på grund af dette år kniber det for tesen. Det, 1864 betyder, er jo ikke det, at Grundtvig nu blander kristendom og folkelighed sammen, selvom han taler mere om kristendommen i folkelige sammenhænge. Det sker kun, når Grundtvig er svækket (s. $716 \mathrm{ff}$ og s. $724 \mathrm{ff}$. I parentesen kan jeg godt sige, at når man vrænger ad mine undersøgelser af de 
pågældende tekster, så skylder man selv at give en anden tolkning, der viser, at de udmærket stemmer med Grundtvigs normale tankegang).

Men Aronson mener som sagt, at min tese går ud på, at det menneskelige og det kristelige »isoleres« fra hinanden, mens den bygger på en saglig adskillelse, der er forudsætningen for, at Gud og menneske kan mødes på evangelisk og antignostisk vis i kirken, og for, at der nu kan finde en »fri Vexelvirkning « sted mellem det kristelige og det folkelige, hvad der var umuligt før ı832. Og efter ı864 bliver der tale om et »trøsteligt« forhold mellem danskhed og kristendom og om en fælles front mod det tyske væsen ( $\min$ bog $\mathrm{s} .704 \mathrm{f}$ ). Men den saglige adskillelse står stadig klart. Og nytårsdag i867 får vi af ham selv at vide, at adskillelsen og det deraf følgende valgsprog »først Menneske, saa Kristen « stadig har sin fulde gyldighed (s. $73^{2} \mathrm{f}$ ). Her er stadig ikke tale om, at skabelse og frelse gensidigt betinger hinanden - jfr. Aronsons samsyn. Og når der på dette punkt er fastslået kontinuitet fra $1_{32}$ til ı867, skulde det være berettiget at tale om Grundtvigs »endelige livssyn« (Gr.St. s. 79). Kun de allersidste par år er tvivlsomme.

Sin omtale af min bog indleder Aronson (s. 7 I f) med at citere den tekst, hvorfra jeg har hentet mottoet til mit arbejde, for at vise, at sammenhængen i den »direkt strider mot huvudtesen $\mathrm{i} \gg \mathbf{M}$. først《«. Aronson har imidlertid misforstået dette sted fra »Danskeren« IV (men har ret $\mathrm{i}$, at artiklen er padagogisk interesseret). Grundtvig polemiserer her voldsomt mod den tyske (gnostiske) visdom, der vil adskille sjæl og legeme, i modsætning til »det christelige Lys«, som gælder »det hele Menneske, som han staar og gaar i denne Verden, lyslevende« (D. IV, s. 283). Og det beråber sig da på vor egen erfaring, så vidt den går (s. 285), idet det bærer sig ad med os, ligesom vi, hvis vi er kloge og kærlige forældre, når vi oplyser vore børn om livet: vi begynder med det, de små kender eller lærer at kende, når de lukker deres øjne op, og prøver så gradvis at udvide deres synskreds i stedet for at pine dem fra barnsben af med bogstaver og bøger og overhøringer. Den rette fremgangsmåde er kun mådeligt prøvet i Danmark, skønt det kristelige lys i tusind år har skinnet her og har båret sig ad med os, som vi burde bære os ad over for vore børn, og det har derfor klaret mange panderynker blandt danske. Derfor må vi have en følelse af, at en kristen oplysningsmåde er den rette menneskelige og - da den almindelig bestrides $\mathrm{i}$ 
verden - også den rette guddommelige, så når vi blot turde for tyskerne, vilde vi anderledes godt end hidtil benytte os af den kristelige oplysning og »efterligne« den i hele vor indbyrdes undervisning, børneopdragelse og skoleindretning. Men hvorfor skulde vi danske ikke vove det - vi som har set vor ungdom gå i ilden for, hvad den har kært (i treårskrigen)?

Hvorfor denne tankegang skulde stride mod min tese, begriber jeg overhovedet ikke. Her er jo tale om i almindelig pædagogik at efterligne den menneskelige måde, kristendommen er gået frem på i Danmark, under hensyntagen til det »hele« menneske. Her er tale om analogi, ikke om »samsyn«. Derfor skal vi gå imod det tyske gnostiske menneskesyn i vor opdragelse. Aronson citerer, at jeg om denne afhandling »Dansk Oplysning « siger, at den »går nærmere ind på det særlige ved dansk tænkemåde og drager grænselinier - nu ikke i forholdet til kristendommen, men til fremmed filosofi«. Karakteristikken er - trods Aronson - korrekt, som det gengivne har vist det: grænselinien er ikke trukket $\mathrm{i}$ forholdet til kristendommen, hvis menneskelige fremgangsmåde vi jo netop skal lære af, men i forholdet til den fremmede tyske filosofi. Men mener Aronson da, at ethvert citat, hvor kristendom og menneskeliv på en eller anden måde er sat $\mathrm{i}$ forhold til hinanden (som her analogiens forhold), får min tese til at falde? I så fald er det ikke sært, at han taler om mine fortielser og min undertrykkelse af besværlige tekster. Jeg har imidlertid med flid netop behandlet alle de ud fra mit synspunkt mere problematiske tekster, som jeg har kunnet finde både i det trykte og det utrykte forfatterskab. Det er da også fra anden side blevet noteret.

Endnu et $-\mathrm{i}$ anledning af den anførte tekst fra »Danskeren«. Aronson angriber min bedømmelse af den rolle, modsigelsens grundsætning spiller i den, og anfører Grundtvigs egne ord om, at denne sætning er »den Vej, hvorpaa jeg er kommet til min danske Oplysning«. Hertil vil jeg svare, at det er en sag for sig, at fundet af denne sætning blev meget betydningsfuld for Grundtvigs vej fremad. Men når jeg hævder, at den her virker som en reminiscens fra hans apologetiske dage, så bygger jeg på en nøje tolkning af teksten (en hel side), som Aronson slet ikke anfægter. Han henviser blot til min »subjektive« metode. Men hvor stor en kvantitativ rolle sætningen end spiller, så er det dog ikke Grundtvigs logik, der er afgørende for bestemmelsen af, hvad dansk oplysning vil sige (hvad jo da også vilde være underligt), men det virkelige liv og dets afspejling i hverdagssproget. Man kan selv kontrollere min kommentar (s. 634). - Aronson bruger (s. 73) denne artikel som eksempel 
på de overraskelser, han har fået ved at gå fra mit arbejde til Grundtvig selv. Forhåbentlig bliver han overrasket endnu engang, når han påny slår efter og ser, hvad der står i teksten.

Det samme gælder et andet sted i »Danskeren« IV (s. 807 f), hvor han om min opfattelse simpelthen siger »nonsens« (s. 93). Det drejer sig om den berømte samtale mellem Grundtvig og Marheinicke. Jeg har sagt (s. 749), at Grundtvig i denne sammenhæng har opfattet modsætningen liv og død som udtryk for kulturkampen og altså ikke har set den i teologisk perspektiv. Den anledning, der får Grundtvig til at tænke på samtalen, er omtalen af den danske ungdom, som nu midt $\mathrm{i}$ århundredet har langt lettere ved at vågne til folkelig bevidsthed og nå til en levende betragtning af menneskelivet end ved århundredets begyndelse. Derved er Grundtvig kommet til at tænke på »sin« modsætning liv og død. Anledningen er altså kulturel. $\mathrm{Og}$ udnyttelsen også: jo mere det danske folk »smager paa det Ord «, jo enigere vil det blive med ham (i at kæmpe »for Livets, for Menneskelivets Skyld«, jfr. tidligere), jo mere gavnligt vil det udrette og jo lykkeligere vil det blive. Her må Aronson simpelthen have undladt at slå op - i tillid til gængs opfattelse (»rent nonsens för var och en som har kännedom om $\mathrm{Gr}$ «).

Jeg håber gennem min gennemgang af de tekster, Aronson har henvist til, at have i det mindste rokket ved det indtryk, man gennem hans kritik uvægerlig må have fået: at jeg bevidst uredeligt eller blindet af en fiks ide (tesen) har sorteret og udvalgt mine tekster efter eget forgodtbefindende. Påstanden herom forklares som sagt af, at han ikke har fattet min tese, så hans beskyldninger er absolut fremsat i god tro. Men foruden tesen forstår han heller ikke min metode og mit mål.

Her er vi da også fra starten helt forskelligt stillet. Han har fået stillet sin opgave ad akademisk vej. Prof. Wingren har givet ham den (disp. forordet). Jeg er gennem min opdragelse og som præst blevet stillet over for problemet Grundtvig og er da gået til kilderne for at se, om han virkelig skulde være blevet rigtigt forstået. Men vi er enige om, at hovedproblemet hos Grundtvig er forholdet mellem det menneskelige og det kristelige. At dette spørgsmål stadig er aktuelt, alene fordi det altid må rejse sig, hvor kristendommen når hen, spiller selvfølgelig ingen rolle for Aronson (i en »akademisk avhandling «!). Men det spiller en rolle for mig. Hvis Grundtvig ikke havde haft noget at sige i dag, vilde 
jeg aldrig have skrevet om ham. Men det kan da ikke diskvalificere mit arbejde som en historisk undersøgelse, at problemet deri er 》grundmenneskeligt « (Gr.St. s. 78), og heller ikke, at min motivering for at søge det frem har været den, at Grundtvig derved bliver »levende«. Og netop fordi det er hans eget grundproblem, man dér får fat i, viser det sig også at være den »virkelige« Grundtvig, man møder igennem det. Den gængse opfattelse, at det er opgøret med det gamle bibelsyn, der i i 825 gennem opdagelsen af trosbekendelsen fører Grundtvig frem til den endelige klarhed, viser sig ikke at holde stik. Sit egentlige problem har Grundtvig ikke dermed fået løst. Det sker først gennem den saglige adskillelse af det menneskelige og det kristelige i 1832 , i hvilket år »den mageløse opdagelse« da også får nyt indhold.

At påvise dette er en udmærket opgave selv for en akademisk afhandling, i hvert fald i dansk betydning af det ord - selv om der som sagt kun kan blive tale om sandsynliggørelse. Og, som også før sagt, må de personlige forudsætninger uvægerlig spille ind. Det viser sig ikke mindst, når talen bliver om sekulariseringstanken. Alene fordi den kan erklæres for at være af tysk oprindelse i teologien, er den åbenbart for Aronson på forhånd kompromitteret. Vi er enige om, at den oprindelig betyder, at det borgerlige liv (mere specielt kirkegodset) frigøres fra sin dominans af kirkelige institutioner og religiøse forestillinger (Gr.St. s. 82), og Aronson godkender ordets anvendelse - i tilfældet Grundtvig - hvad borgerliggørelsen af kirkeinstitutionen angår. Men når han selv i den forbindelse nævner frigørelsen fra religiøse forestillinger, måtte han da også godkende, at udtrykket kan bruges om »afkristningen « af historiesynet, folkeoplysningen, videnskaben, politikken, det poetiske billedsprog, ja, af selve den historisk-poetiske livstolkning (»anskuelsen«, filosofien, om man vil). Alt dette skiller Grundtvig jo bevidst ud fra den kristne tro - den skal her ikke »herske« mere, så lidt som over kirkegodset eller i kirkeinstitutionen.

Afgørende i $183_{2}$ er denne adskillelse af anskuelse og tro. Den mosaisk-kristelige anskuelses sekularisering betyder, at den er blevet skilt ud fra troen og nu kan være fælles for kristne og ikke-kristne. Det timelige er adskilt fra det evige, idet hvad der hører tiden og verden til forstås som blot »timeligt«. I stedet for at gå ud fra tysk tankegang, har jeg holdt mig til Grundtvigs, og Aronson har ret i, at vi her har »den springande punkten« (s. 83). Men igen dukker hans sondring mellem det psykologiske og det systematiske op. Han siger, at Grundtvigs omvendelse til menneskelivet primært har »psykologisk innebörd«, mens 
sekulariseringen i anden række (hos mig) bliver en faktor, der bestemmer tolkningen af Grundtvigs teologi og ideverden overhovedet. Men hvorfor denne sondring? Hvad interesserer Grundtvigs psykologi os? Det er dog kun hans tankeverden, der vedrører os. Og omvendelsen betyder jo dog en ændring netop af hans tanker, hans livssyn. Jeg har brugt hjælpeordet sekularisering - hvad skal man ellers sige? Grundtvigs eget ord »Upartiskhed « peger i den retning, men er ikke udtømmende. Men i fremmedordet ligger, at verden bliver set som verden, som den virkelige, foreliggende verden, som ikke skal skabes om, hverken ved hjælp af tysk filosofi eller ved kristendommen.

Aronson har en mærkelig kommentar til noget, jeg skrev i Kr. Dagblad ( 18. 2. 1964) : »Kristendommen er nu til for menneskelivets skyld evangelisk forstået. Verden skal nu ikke længere formes kristeligt - efter guddommeligt mønster (183I). Synet på den, ligesom også på kirkeinstitutionen, sekulariseres«. Han skriver: »Ideologiska och teologiska tankegångar trängar här tätt inpå varandra« (s. 85). Ideologisk godkender han talen om sekularisering af kirkeinstitutionen - og nu også af skolen. Men han har uden tvivl misforstået tilføjelsen »evangelisk forstået«, idet han tror, at den hænger sammen med det umiddelbart foregående »for menneskelivets skyld «. Men meningen er den, at kristendommen er til for livets skyld, nu ikke længere som et mønster for, men som et evangelium til livet. Jeg vilde tro, at Aronsons kommentar om mine »omkastningar « $\mathrm{i}$ tankegangen (der er nu tale om en kristen forudforståelse) bliver overflødig på grund af en fejllæsning, som jeg dog kun kan forklare mig, fordi vi tænker så forskelligt - og forstår Grundtvig så forskelligt. Når Aronson taler om ideologi og teologi, er meningen en anden, end når jeg taler om Grundtvigs menneskesyn og hans kristendomssyn.

Alligevel er der et spørgsmål, som jeg i min bog ikke har besvaret, da den er skrevet historisk-genetisk, som en kronologisk tolkning af tekster, og ikke systematisk. Det har fået Aronson - og også andre - til at spørge: er forudsætningen for sekulariseringen hos Grundtvig ikke et »kristen først«? (Gr.St. s. 86). Spørgsmålet er berettiget.

Jeg har sagt, at Grundtvigs sekulariserede skoletanker $\mathrm{i}$ en vis forstand har hans kristne tro til forudsætning. Dermed mener jeg, at havde han ikke tumlet med spørgsmålet om kristendommen, var han ikke her kommet til klarhed. Havde han ikke før hævdet, at oplysningen skulde føre til himlen, havde han heller ikke demonstrativt fået slået det fast, at skolen er en skole for livet, det timelige liv. Rent biografisk afsløres gennem et profant chok, opdagelsen af menneskelivet - en falsk kristen- 
dom for ham. Hvorefter han siger sit menneske først - vendt mod den falske gnostiske kristendomsopfattelse. Kristendommen er hans historiske forudsætning. Men deraf udleder han ikke et programmatisk »kristen først «. Da han er nået til klarhed over den ægte kristendom, må det programmatisk hedde: menneske først.

Sekulariseringen er i første omgang polemisk vendt mod den falske kristendom: menneskelivet betyder noget i sig selv. Det frigøres fra ikke blot den herskende kirke, men fra den herskende kristendom, den, der forstås som en ideologi i stedet for som en begivenhed, et skabende og genfødende ord (ordet ved dåben skaber, hvad det nævner). - Mon Aronson kan godkende denne brug af ordet ideologi?

Men i anden omgang forstår Grundtvig, at der ud fra den sande kristendom må sekulariseres, fordi kristendommen er sandhedstroen. Historisk set er det kristendommen, »vor oplyste Verden maa takke for alle sine almindelige begreber om Menneskelivet i det hele, med fremskridende Oplysning og endelig Forklaring «, skønt den vantro verden praler deraf som sin egen opfindelse (US IX s. 579). Ligesådan må den kristne menighed nu - i oplysningstiden - gennem en lignende udstrakt oplysning på Herrens vegne gøre sig jorden underdanig (s. 580). Menigheden vil ganske vist anse det frie forhold til videnskabeligheden som en fare for kristendommen, men Kristi tro kunde ikke være sandhedstroen om »det grundvirkelige Forhold mellem Sandhed og Løgn, Lys og Mørke, Liv og Død, eller mellem Gud og Verden, Gud og Menneske, Aand og Kjød og Tid og Evighed «, hvis ikke troens ånd i sin egenskab af sandhedsånden $\mathrm{i}$ tidens løb »udviklede og klarede den menneskelige Oplysning om alle disse Grundforhold« (s. 58 I jfr. Gr.St. s. $8_{3}$ f). Den (særligt) kristelige oplysning må vise, hvordan alt timeligt har sin oprindelige sammenhæng i Gudsordet fra evighed, er samlet i Kristus og nu lever og rører sig i hans menighed. - »Den christelige Børnelærdom«, som jeg her refererer, er skrevet for »Medkristne«, ikke for andre.

Men der er en oplysning, der ikke er særligt kristelig, og som udgør forudsætningen for menighedens tro. Andens narvarende verden skal oplyses, da den er spejlet for den fraværende verden (som man har dyrket i stedet for). Derfor har Grundtvig så ivrigt stræbt at oplyse forholdet mellem det kristelige menneskeliv og det menneskelige folkeliv, selvom han har vidst, at man vilde korse sig over hans verdslighed. Grundtvig ved altså, at hans oplysning om det menneskelige folkeliv er af verdslig art. Den er sekulariseret. $O g$ han ved, at verden ikke derved bliver blidere stemt mod det kristelige menighedsliv (s. $5^{85}$ ). 
Oplysningsværket må hos os, netop efter den menneskelivets grundlov, der skal oplyses (ikke nogen etisk lov!), gå ud fra den danske tankegang og de danske tilstande og må stile på klarhed over hele det underfulde menneskeliv. Og den er på linie med den folkelige bevægelse i det I9. årh. (s. 586). Hos os - d. v. s. hos Grundtvig selv - er den udsprungen af »Troen paa det levende Guds-Ord og Trangen til det kristelige Menighedsliv« (s. 587). Men det store omsving i oplysningen, der altså ikke behøver at have dette udspring, vil ikke gøre verden kristelig. Tværtimod vil troens, tungens og pennens frihed gøre angrebene langt mere hensynsløse, end de før har været, og troen vil ikke kunne støttes af den ægte menneskelige oplysning. Ingen uden Kristus selv kan forsvare den (s. 589).

- Aronson indvender mod min tolkning af disse sider, at jeg i tilslutning til dette Grundtvigs dogmatiske testamente (I86I) indfører sekulariseringsbegrebet. Det af os begge anførte citat markerer jo dog »enheten i Grundtvigs åskådning« (s. 84). Jeg tilføjer: ja, i hans kirkelige syn. Her er der samsyn mellem menneskeligt og kristeligt - »med stora öppningar för det mänskliga«, tilføjer Aronson. Ja, men denne åbenhed fører netop til sekulariseringen, som min parafrase af det, der følger citatet, har vist det. Den menneskelige oplysning, som hos Grundtvig har sit (historiske) udspring i hans kamp for at få klaret kristendommens mening, er ikke af anden art end den, der er udsprunget af det 19. årh.s folkelige bevægelse. Den har han jo selv tilsluttet sig. Og da troens ånd er sandhedens ånd, må den fremme denne oplysning. Grundtvig er »Fürsprecher für die Säkularisierung, die eine Folge des christlichen Glauben ist« (s. 86). Så denne tankegang behøver man ikke at gå til Tyskland efter. Han ved desuden, at den sekulariserede oplysning, som troen fordrer (men ikke er den eneste forudsætning for), vil kunne føre til angreb på kristendommen - vi kan bruge det af Aronson anførte udtryk: sekularismens angreb. $\mathrm{Nu}$ er det så kristendommen selv, man vil sekularisere.

Bemærkelsesværdig er Aronsons forlegenhed m. h. t. mit arbejdes karakter. Er bogen videnskab eller opbyggelse eller begge dele? Er den biografisk, alment idehistorisk, kirkehistorisk, teologisk eller »ideologisk «? Det rette svar er - mener han - at bogen er lidt af hvert eller alt dette (s. 8o). På det sidste spørgsmål vilde jeg selv svare: ingen af delene. På det første således: der er tale om et forsøg på så nøjagtigt som mu- 
ligt at nå frem til Grundtvigs arbejde med og hans afklaring af det, der var hans problem, med alt, hvad der deraf fulgte i hans tankegang. For den, der har føling med det pågældende problem, kan bogen blive til »opbyggelse« som for den, der skrev den. Hvorfor harcellere over det? Hvis problemet er tilstrækkelig alment - som Grundtvigs var det, ophæves tids- og personafstanden, man er »samtidig « med den, der har kæmpet med problemet. Det at Grundtvig er død, er da uvæsentligt. Han kan tale og udfordre en tværs over afstanden. Det er i hvert fald min erfaring, og uden det havde jeg ikke ofret år på den sag. Der er da heller ikke noget, der principielt taler imod, at den historisk set virkelige Grundtvig er den levende Grundtvig. Ja, det burde være fremgået af Aronsons systematiske arbejde - selvom videnskab for ham intet har med det, der kan »bygge op«, at gøre. Jeg tror dog selv, at selvopgørets kategori er bedst egnet til at skabe samtidighed med de døde. I hvert fald med Grundtvig. Og hvad gør det så, at Aronson ikke har haft en bås at putte mit arbejde i?

Han gør sig mange spekulationer m. h.t. min teses forhistorie. At jeg fra starten har haft en arbejdshypotese, der viste sig at holde stik, er jo ikke i sig selv tegn på, at der er øvet vold over for materialet. Det utrykte forfatterskab viste sig at svare til det trykte - men i høj grad tillige at belyse det tryktes tilblivelse og derved dets mening. Tesen er derfor ikke blevet ændret, men i høj grad tilslebet under arbejdet. Ikke mindst 3. del af Søndagsbogen var mig en overraskelse. Den førte nøjagtigt frem til det springende punkt i udkastene til Nordens Mythologi (adskillelsen af anskuelse og tro).

Indvendingen mod, at man bruger bruddet $\mathrm{i}$ I8 32 som nøgle til at læse Grundtvig forfra, begriber jeg ikke. Begtrup har brugt 1825 som nøgle til læsning af prædikenerne forud, men er derved ikke blevet opmærksom på, hvad der egentlig var problemet for Grundtvig, da han skrev dem. I 1832 afsløres det, hvor det lå. Derudfra forstår man så meget, der før var uforståeligt, f. e. Grundtvigs to farveller til prædikestolen (som han ganske vist selv har givet mange forklaringer på) og de skarpe periodeskel i hans udvikling. Aronson finder det forbavsende, at den røde tråd trækkes bagud på en sådan måde, at $183^{2}$ rent ud kan være årsag til formuleringer årtier tidligere. Men der er da ikke noget mærkeligt $i$, at det problem, der når til sin endelige løsning i I832, kan finde udtryk $\mathrm{i}$ formuleringer længe før (f. e. at menneskekundskab er nødvendig for Gudskundskab, I823). Har man fat i, hvad Grundtvig slås med, går meget op for en undervejs. Og man forstår så også, at der 
kan være tale om afsporinger undervejs - og at Grundtvig selv siden kan kalde Kirkens Gienmæle et fortvivlet luftspring, uanset den blivende betydning, selve opdagelsen af trosbekendelsen fik. Men hvor var Grundtvig af 1825 endt uden 1832 ?

Da det ikke var min opgave at give en skildring af hans kirkesyn, er meget stof gledet ud af synsfeltet - men også for Aronson (»Kirkelige Oplysninger. . .«, store dele af Børnelærdommen, mange småbøger og artikler). Det kommer af, at vi har fælles tema. Men hans teologiske udgangspunkt fører ham selvfølgelig videre omkring i det kirkelige forfatterskab. Jeg gentager imidlertid: for mit emne relevante tekster har jeg ikke udskudt. Emnet er forholdet mellem det menneskelige og det kristelige. Derfor er det ikke rigtigt, når Aronson vil hævde, at vore bøger kun i en vis grad er kommensurable, da hans er teologisk, og min »ideologisk« (s. 89). »Adskillelsen«, som jeg har tolket den, har i højeste grad teologisk relevans. Den fører jo ind i et nyt kristendomssyn. Hvordan kan Aronson kalde min skildring heraf »ideologisk «?

Han klager over, at jeg ikke historisk har skildret den bodskristendom, Grundtvig gør op med. Det har jeg ikke fundet nødvendigt, da det er hans selvopgør, det drejer sig om, så bodskristendommen skulde skildres ud fra hans egen opfattelse af den (men nu har Bugge analyseret hans fars kristendom, og billedet stemmer med det, jeg ad den anden vej kom til). At Aronson ikke synes at kunne genkende Irenæus' gnostiske modstander i den lutherske bodskristendom, forstår jeg ikke. Han ønsker bl. a. historisk bevis for, at »den lutherske pilgrimskristendom《 iflg. sit væsen må advare »selv mod Skaberens eget værk« (s. 76). Min påstand er dog ikke af historisk art, men er født ved tolkningen af en ganske bestemt tekst, en selvopgørsprædiken i SB III. Kan den tolkes på anden måde? ( $\min$ bog s. 72 ).

Imidlertid må jeg gøre Aronson en indrømmelse. Han har virkelig (s. 76) grebet mig i forkert citat. Ikke i min bog, men i et foredrag, der blev trykt i »Højskolen til debat«, og hvori jeg pr. hukommelse citerede det digt, hvor Grundtvig fortæller, at faderen kom ind i stuen, hvor drengen sad og læste, og »lod sig Læsningen fortælle, retted alt med Kristendom《. Der skulde stå ikke »alt«, men »den«. Aronson påpeger sagen, da vi her står ved »en viktig punkt« i min dokumentation! Imidlertid betyder sagen ikke noget. »Når (hver gang) faderen kom ind, rettede han læsningen (enhver læsning) med kristendom«. Men i hvert fald rettede Grundtvig i sin ungdom alt med kristendom, og hvorfor Aronson ikke vil godkende det, er ubegribeligt. Måske skyldes det 
dog, at han i sin bog ikke har forstået Grundtvigs omslag på dette punkt. Han anfører jo et sted fra I83 I (om kristendommen som et ophøjet mønster til reform af menneskelivet) på linie med Grundtvig efter I832 ( $\min$ bog s. 763 ).

Aronson har fundet det umuligt at gå ind på alle punkter i min kritik af ham (s. 89). I det foregående har jeg vist (trods pladsbegrænsning) svaret på det væsentligste af hans modkritik, men svaret forudsætter i høj grad min udførlige kritik (s. 746 ff), som jeg ikke kan se har vist sig uholdbar. Det er da også forbavsende lidt, Aronson har haft at svare på den. Han har i stedet ført krigen over i fjendens lejr! Det er også rimeligt, at man må stå for skud, men det er da teksttolkningen, det står på. Dog, som Harnack sagde, hvis man er svag i sagen, kan man altid snakke metode. Det har Aronson brugt alt for meget plads til.

Forholdet mellem Grundtvig og Sverige var ikke for godt i gamle dage. Men da nu en svensker påtog sig det kæmpearbejde at sætte sig ind i hans forfatterskab og tilmed i den problematik, han har efterladt sig i Danmark, var der en chance for, at den kunde komme hans landsmænd ind på livet. Efter mit (subjektive) skøn er chancen glippet. I sagens interesse gjorde jeg, hvad jeg kunde, for på forhånd at forstyrre Aronsons systematiske cirkler (jfr. hans egne ord herom s. 8I). Det lykkedes ikke. Der kom et »system《 ud af det, hvorved teksterne blev vredet af led.

En ting er jeg ked af: min kritik har tvunget Aronson tilbage til tidskrævende Grundtviglæsning til trods for, at han er kommet over på helt andre arbejdsfelter. Men vi må nu engang tage konsekvensen af, at vi hver har leveret en Grundtvigtolkning. Havde manden været lykkeligt død, havde vor strid kun været en prestigesag, kun en sag om videnskabelig formåen, og kunde afblæses. $\mathrm{Nu}$ er han ulykkeligvis levende. Det er alene derfor det er nødvendigt, som Aronson siger det, at »kampen fortsætter«.

\section{WILLIAM MICHELSEN}

Da Michelsen ikke kunde være til stede og opponere ved mit forsvar, sendte han et indlæg til Dansk Udsyn ( $1964 \mathrm{nr} .6$ ), som jeg i samme nummer på opfordring svarede på. Hans indlæg i denne årgang af Gr.St. er en fortsættelse af vor debat. 
Selvfølgelig har Michelsen ret i, at selv om man korrigerer referatet af samtalen mellem Grundtvig og Trier, kan man ikke derved modbevise hans påstand, at Grundtvig til sin død fastholdt »den bibelske betragtning af verdenshistorien«. Men i sin bog opfatter Michelsen da også kun historien som »et slående udtryk « for, at Grundtvig havde det samme bibelske historiesyn til sin død, og mener, at det vil kunne godtgøres ud fra en gennemgang af »hele den anden fase « $\mathrm{i}$ forfatterskabet, idet han jo hævder, at historiesynet var »det samme i 1833 som i I8I2, I8I4 og I8I7《 (s. 4I). Som Michelsen gengiver den lille historie, svarer den da også til det »bibelske« historiesyn, som Michelsen anser for det konstante: »Historien er for Grundtvig som for Paulus virkeliggørelsen af Guds bestemmelse med mennesket. Det jødiske folks og den kristne menigheds historie danner så at sige rammen om hele verdenshistorien og giver den sammenhæng. Verdenshistorien er menneskets frelseshistorie, og mønsteret for denne opfattelse er Det gamle Testamentes skildring af Israels historie. Hele historien bliver for Gr. som for Paulus og de gammeltestamentlige forfattere Guds førelse og opdragelse af sit folk gennem onde og gode tilskikkelser; Gud er historiens herre, han griber ind i den, når han vil, og leder menneskene og folkene efter sin plan, også mod deres vilje. Han opdrager sit folk, ikke blot ved at straffe det, men også ved at vise det sin store kærlighed: historien viser, hvorledes hans forjættelser er gået i opfyldelse. Og således har han ført os lige fra verdens skabelse, trods syndefaldet, gennem frelsen ved Jesus Kristus, frem mod det evige liv« (s. 3I).

Michelsen har ret $i$, at dette er Grundtvigs historiesyn i 1812, men hverken $\mathrm{i}$ at Håndbogen $\mathrm{i}$ verdenshistorie er skrevet ud fra dette syn (jfr. disputatsen), eller i, at de af ham nu anførte steder fra $\mathrm{HV}$ beviser, at Grundtvigs personlige overbevisning trods alt slår igennem, også når han vil skrive en »verdslig statshistorie«. Det Grundtvig vil med sin skildring af Jesu liv - som jo da vitterlig hører med i menneskeslægtens og i staternes historie - er netop her at holde sin personlige overbevisning udenfor. At Grundtvig ved at gengive evangeliernes beretning $\mathrm{i}$ virkeligheden gengiver de troende kristnes vidnesbyrd og ikke en beskrivende historisk beretning, sådan som vi i dag forstår historieskrivning, vidste han ikke. Men på sin måde måtte han da skelne mellem troens og videnskabens forhold til beretningerne og mellem de kristnes og naturalisternes forskellige opfattelse af den evangeliske historie. Jeg har i min bog kommenteret Grundtvigs behandling af den (s. 328), men vil her gentage og uddybe, hvad jeg skrev. 
Gr. refererer (s. 524) evangeliernes beretning om Jesu korsfæstelse og opstandelse, men siger udtrykkeligt, at han ikke vil »paabyrde StatsHistorien som Kiends-Gierninger, hvad efter Sagens Natur kun kan være »Troes-Artikler i en Kirke««. Jesu liv hører »for største Delen« til »Troens Hemmeligheder«. Men han er dog enestående i verdenshistorien ved at have bevirket de historiske kendsgerninger: kristenheden og kristendommens tilblivelse. »Men hvem han i Grunden var: enten blot en giennem det Ebraiske Folke-Liv forklaret Abraham eller tillige en neddalet Guddom, det maa vist nok til Verdens Ende staae videnskabelig uafgjort « (s. 525) - Det er mig uforståeligt, at Michelsen ikke kan se, at Gr. her bevidst har forladt det paulinske historiesyn som historisk grundlag, også når han fortæller Jesu historie. Han har netop holdt sin personlige overbevisning udenfor. Ja, han indleder beretningen med at gengive Tacitus' ord om »en vis Christus, som Pontius Pilatus korsfæstede i Jødeland « (s. 556) for netop at holde sig til de foreliggende, også hedenske kilder til de kristnes historie. Fra Tacitus går han til Det ny Testamente. Her siger kilderne da, at Jesus viste sig at svare til de jødiske spådomme om Kristus (Messias). Det af Michelsen anførte citat desangående er fra Gr.s side fuldstændig nøgternt og beskrivende, og det er også historikeren, der derefter erklærer, at Jesu taler var lige så mageløse som hans jærtegn, idet han så gengiver Jesu unægtelig enestående forkyndelse, hans skildring af Guds rige.

Efter på denne rent menneskeligt vurderende måde at have skildret »den mageløse Historie om Christus og hans Riges Stiftelse « drøfter han (som af Michelsen citeret) indvendingerne mod beretningen, der ikke afvises ud fra den paulinske tro, men ud fra mangelen på andre kilder! Grundtvig selv holder på beretningens »Rimelighed«, da kristendommens virkninger $\mathrm{i}$ verden ellers vilde være uforklarlige. En rent logisk slutning.

Noget andet er, at der (iflg. Gr.) kan gives en naturalistisk (romantisk-naturfilosofisk) forklaring på, hvad der står i Bibelen, så at alt i virkeligheden forklares »paa naturlig Maade«: guddomsånden i mennesket var selv skyld i frembringelsen af Jesus som den store læremester, der derefter hæver enhver, som efterligner ham, til sin herlighed (jfr. H. N. Clausens kristendomsopfattelse). Andre vil gå imod den naturlige filosofiske forklaring, men videnskabeligt kan intet fastslås, udover at kristendommens virkninger i verden må have en årsag. Grundtvig finder den i »den Ebraiske Anskuelses Rigtighed, Christi Guddom og hans Magt til at opvække aandelig Døde« (s. 564). Det, der i dag er vanskeligt at 
fatte for hans læsere, er, at der her er tale om en naturlig forklaring på de virkninger af kristendommen, som jo er kendsgerninger i statshistorien. Men sådan tænker altså Grundtvig i i836. Og selvom han nævner både skabelse, syndefald og oprejsning, er betragtningen ikke bundet til Paulus' tro. Fremstillingen er bevidst moderne - som man i begyndelsen af det 19. årh. kunde være moderne.

Når jeg i øvrigt (i Dansk Udsyn) spurgte Michelsen, hvordan han kunde mene, at historiesynet i HV svarede til Paulus' frelseshistoriske syn, så tænkte jeg selvfølgelig ikke på, om det syn var gengivet under skildringen af kristendommen $\mathrm{i}$ bogen, men om det bar hele fremstillingen af menneskeslægtens historie. Og det er der jo ikke tale om. Hvor er tanken (fra I812) om Guds ledelse af folkeslagene under opdragelse og tugt eller vidnesbyrdene om hans kærlighed? Hvor er ligheden med »Christenhedens Syvstjerne«, der jo er en kirkehistorie? Forskellen på 1812 og I833 er ikke blot opgivelsen af gennem verdenshistorien at kunne påvise sandheden af Paulus' syn. For det, Grundtvig nu vil, er at fortælle verdenshistorie på ubibelsk måde. Derfor er han undervejs blevet så begejstret for at få rakt Polybs hedenske nøgle til historien. Spørgsmålet er herefter ikke, om Grundtvig enkelte steder evt. kan vakle under gennemførelsen af denne linie, men om hans grundhensigt med at skrive historie på det nye grundlag. I Michelsens citater fra gengivelsen af Jesu historie vakler han imidlertid ikke. Her passer han tværtimod nøje på. US VII s. $379 \mathrm{f}$ udtaler han sin på tro begrundede personlige forvisning om, at der virkelig vil hæve sig en nyårstid inden for kristenhedens grænser, men skiller bevidst det spørgsmål fra mulighederne for videnskabeligt at påvise spirerne til en sådan nyårstid.

Michelsen vil antagelig til denne sondring sige: jamen, det er jo det, jeg siger, at Grundtvig rent privat fastholder det bibelske syn, selvom han som historiker er gået over til det græske. Dertil vil jeg for det første svare, at Michelsen med sin argumentation mærkeligt nok nu vil vise, at Grundtvig for et bestemt stykke histories vedkommende ikke holder denne grænse (hvad han imidlertid gør undtagen det enkelte sted US VII s. $702 \mathrm{f}$, der stammer fra en uklar periode $\mathrm{i}$ hans alderdom, se min bog s. 725. Heller ikke den af Michelsen påpegede »meget sigende« sammenstilling af Polyb og Moses siger, hvad Michelsen synes at mene den gør. Moses er en med Polyb jævnbyrdig historieskriver, men står ikke i et andet plan end grækeren (US VI s. 450). Fortalens nye placering af begrebet det mosaisk-kristelige har jeg omhyggeligt kommenteret (s. 322). Jeg ved ikke, hvad det er, jeg skulle have »læst hen« over). 
Dernæst: Grundtvig har ved at skelne mellem sin tro og sin historiske anskuelse ikke blot gjort op med sin tidligere dømmende, »partiske« historiske anskuelse, men også med den tro, der for ham var eet med denne anskuelse (bodskristendommen). Kristen tro er herefter for ham et værgeløst evangelium, adskilt fra enhver moralsk norm. Det nye i i833 er ikke blot, at Grundtvig opgiver at bevise sit syn. Selve synet er nyt, det vidner både $\mathrm{HV}$ og hans prædikener og salmer om.

Michelsen fastholder de ord, hvormed han (i Dansk Udsyn) mente at kunne gengive Grundtvigs menneskesyn, og oplyser, at ordene skal være en omskrivning af, hvad Grundtvig mente at have tilfælles med naturalisterne (US V s. 4o If). Han undrer sig derfor ikke over, at ordene mest har mindet mig om den tro, Grundtvig fandt hos sine naturalistiske modstandere. Men det er jo netop troen, Grundtvig ikke vil have fælles med dem! Den tro nemlig, at mennesket »ved Jesu evangelium« dog er i stand til at bevæge sig hen imod det evige mål. Det jødiske syn på mennesket som skabt, faldet og bestemt til frelse mener han at kunne dele med dem, men ikke deres tro på ved hjælp af Jesu evangelium at kunne bevæge sig mod målet. Det syn vil man intetsteds kunne finde hos den afklarede Grundtvig. Og Michelsen kan jo ikke med »bevægelsen« mene den vækst mod målet, som Gud giver. For dette syn har han netop ikke fælles med naturalisterne. Troen på den vækst har de ikke.

- Grundtvigs tankegang kan være svært tilgængelig, også for teologer. Men der er god sammenhæng i den - efter selvopgøret i I832. Jeg er enig med Michelsen $i$, at hele hans kamp med problemerne op til dette år kan ses som et selvopgør. Men det afsvækker ikke, at revisionen af hans livssyn i drejeåret var langt mere radikal, end Michelsen ser det. Det er svært at flytte debatten fra et tidsskrift til Gr.St., og det er i det hele taget svært at nå til bunds i uenigheden imellem os - den, der udelukkende drejer sig om Grundtvigtolkningen. Når jeg i min bog imødegik Michelsens syn, var det bl. a. i forlængelse af tidligere mundtlige debatter (der også havde påvirket hans bog), og skal vi fortsætte, må det nok også blive mundtligt. Hvad jeg gerne vil overbevise Michelsen om, er at hans tolkning af den tidlige Grundtvigs historiesyn er præcis, men at det endelige brud med den lutherske bodskristendom medfører et nyt livssyn og dermed også et nyt historiesyn. Han opgiver ikke blot at bevise et bibelsk historiesyn. Han søger at skrive verdenshistorie uden bibelsk nøgle. 


\section{HELGE TOLDBERG}

Da jeg på universitetet forsvarede min bog, meldte Helge Toldberg sig som opponent og fremførte bl. a. den slående indvending mod min datering af prædikenerne i Søndagsbogens 3. del (her SB III), at censor havde givet sit imprimatur I6.3. I83I. Altså måtte bogen have været trykt inden den dag, og altså kunde f. e. påskeprædikenerne ikke være skrevet i påsken I83 I (påskedag var d. 3.4.), sådan som jeg ud fra hovedsagelig indre grunde havde formodet.

Inden sin død nåede Toldberg at udarbejde sin opposition til Gr.St. I964 (ligesom en anmeldelse til Danske Studier i965, som jeg modtog fra ham lige før hans afrejse til London, hvor han døde et par dage efter). Nu har jeg så kunnet gennemgå sagen nærmere - og er til min egen overraskelse nået til det resultat, at jeg kan fastholde min opfattelse. Jeg følger nu Toldbergs argumenter forfra (den evt. læser bedes have Toldberg ved siden).

Toldberg vil datere de flest mulige prædikener så tidligt, han kan. Men brevet fra Grundtvig til Busck 20. 12. 1828 (GBusck s. 70) beviser ikke, at Grundtvig allerede da er i gang med SB III. Han har jo lige afsluttet SB II, og når han siger, at han må se at få 3. del færdig, da der er adskillige ting, han endnu ikke har skrevet rent ud af posen om - så behøver han endnu ikke at have skrevet nogetsomhelst af den, trods ordet »færdig«. »Endnu ikke« refererer sig til de to første bind - ikke til noget, han evt. kunde have skrevet af 3. del. Udtrykket forudsætter jo, at det meste er skrevet. Nemlig to af de tre bind. Toldberg peger selv ikke på mere end nogle få prædikener, der kan være skrevet så tidligt: på grund af, at udkastene er skrevet med fjerpen (s. I8).

Io. I I. I830 skriver Grundtvig til Busck (s. 99) om en prædiken, som han sender, men hvis disposition han ikke er ganske tilfreds med. Den synes dog at være givet til trykken (SB III s. 25 ff). Det mener Toldberg strider mod udtalelsen til Busck af I5. I. I83 I (s. I07), at det gamle duer ikke, det er det ny, der skal til. Men her tænker Grundtvig på den optrykning af en af hans gamle »Smaa-Bøger« (i anledning af kongens fødselsdag), som Busck har foreslået. Heroverfor henviser Grundtvig til »det Nyaar, hvori det gamle Bogstav-Væsen ... skal forsvinde og Aandens ny Væsen komme for en Dag«. Utilfredsheden med en prædikendisposition ligger $\mathrm{i}$ et helt anderledes inferiørt plan end dette, så sammenstillingen kan ikke bruges til noget (Gr.St. s. I3).

Det »nye« præger efter mit skøn prædikenerne i hvert fald fra nr. 6, måske allerede fra nr. 5 (bodskristendommen og det nye kan godt fin- 
des i samme prædiken). Det »nye« præger ligeledes 3. del af afhandlingen »Skal den Lutherske Reformation virkelig fortsættes? « (afsluttet 2 I. I.). Sammenhængen er derfor sandsynlig. Det selvopgør, der præger nytårsprædikenen (nr. 5) - se min bog s. $69 \mathrm{f}$ - har jeg sat i forbindelse med indtrykkene fra den 2. Englandsrejse, men i modsætning til Toldberg mener jeg, at direkte hentydninger til rejsen vilde være utænkelige. Toldberg vil henlægge prædikenernes affattelse til april $1830-i$ anledning af Grundtvigs svar på Buscks spørgsmål ang. døbenavne og binavne ( $\mathrm{s} .92 \mathrm{f}$ ), hvilket problem berøres i prædikenen. Men intet tyder på, at han har skrevet prædikener lige før afrejsen til England (i begyndelsen af maj 1830), og det af Busck forelagte problem kan udmærket dukke op $\mathrm{i}$ en prædiken i årets slutning, når en foreliggende tekst giver anledning til det. Grundtvig skriver ikke prædikener på stedet ud fra tilfældige anledninger.

Toldberg benægter (s. I4), at påskeprædikenen kan være »samtidig med langfredags« på grund af den forskellige bedømmelse af det lutherske tidsrum: det sammenlignes i helligtrekongerprædikenen med Herrens opstandelse, men i påskeprædikenen med hans nedfart til dødsriget ( $\mathrm{min}$ bog s. 70) - men, siger Toldberg, langfredagsprædikenen har samme bedømmelse som helligtrekongerprædikenen. Påskedag refererer Grundtvig imidlertid netop til den første bedømmelse: »Uagtet vi derfor med Rette kalde hvad der skete med Herrens Folk i vore Fædres og Morten Luthers Dage en aandelig Opstandelse ... saa var dog Ligheden med den første Opstandelse kun en Skygge-Lighed «. Herefter er det sammenligningen med nedfarten følger. Omslaget sker altså i selve påskeprædikenen (SB III s. 30 I $\mathrm{f}$ - henvisningen er til I. udgave. Fru Toldberg har venligt overladt mig sin mands eksemplar. Han bebrejdede mig, at jeg havde fulgt 2. udgave). Langfredags- og påskeprædikenen kan altså være skrevet i direkte fortsættelse af hinanden.

I virkeligheden har Toldberg kun den rent »ydre grund « at henholde sig til, når han vil flytte påskeprædikenerne tilbage $\mathrm{i}$ tid, at SB allerede fik imprimatur d. 16. 3. Medio februar er trykkeriet begyndt, men bogen er langt fra at være færdig (Busck s. II7). Toldberg regner med (s. I5), at der til censor senest d. I5. 2. er afleveret mindst 25 ark og slutter ud fra typografien, at der er afleveret 28 ark (s. I-448) - men hans motivering holder ikke. Det er rigtigt, at der er foretaget typografiske krumspring for at få 5 linier til at stå på s. 448, hvorved iflg. Toldberg I9 afsluttede prædikener kunde afleveres til censor. Men typografens umage kan alene begrundes med, at det var nødvendigt at komme om 
på s. 448 med afslutningen, da prædikenen ( + afslutningsstregen) ikke kunde rummes på de foregående sider. Da man alligevel altså skulde benytte s. 448 til afslutningen, så måtte mindst 4 linier føres over på denne side. Det er det mindste, typografen har villet have på en side, hvad man kan konstatere ved at blade $\mathrm{i}$ bogen. Toldberg nævner selv et andet eksempel (s. 513), hvor han mener Grundtvig har grebet ind i korrekturen. Men forholdet er her det samme: de 4 linier på s. $5^{1} 3$ kunde have været på de foregående sider - men ikke afslutningsstregen. Altså måtte satsen strækkes. At det på s. 448 skete ved arkets afslutning, er en tilfældighed.

Der er nemlig en ting, Toldberg ikke har taget i betragtning: de to første bind måtte jo efter hans teori om aflevering opvise et lignende billede. Her måtte også mindst 24-25 ark (med afsluttede prædikener) være afleveret til censor. Men de eneste andre steder i SB, hvor en prædikens og et arks afslutning falder sammen, er i I s. 64 ( 4 ark), og i II s. 336 (2 I ark)! Dermed falder teorien om, at trykkeriet inden I6.3. til censor afleverer de første 28 ark af SB III. Intet taler derfor. Og et andet argument taler imod.

Det drejer sig om trykketiden. Toldberg hævder, at et trykkeri med lidt umage kunde nå at sætte og trykke 448 sider på en måned (s. 16). Ja, det kommer an på, hvor stort et mandskab der blev sat ind. Håndsætning tog lang tid. Og intet tyder på, at Græbes bogtrykkeri har haft så voldsom fart på.

SB III indeholder 659 sider. Sætningen er tidligst gået i gang i midten af februar, og bogen udkom 21. juli. 26. april skriver Grundtvig endnu prædikener (Gr.St. s. I3). En af de første dage i juni rejser han til England, men han kan være blevet ved med at skrive indtil da. Bogtrykkeren behøver sikkert ikke mere end halvanden måned til trykning og indbinding, jfr. at der for Nordens Mythologis vedkommende gik 2 I dage fra imprimatur til udgivelsesdagen, og at Verdenshistoriens I. del fik imprimatur 7. 10. (fortalen, der er skrevet sidst, er underskrevet september 1833) og udkom 32 dage efter. Censor har åbenbart haft alt det trykte til eftersyn - selvom han iflg. Toldberg kun var forpligtet til at læse værker under 24 ark. Til sammenligning tjener, at uindbundne småskrifter udkom fra I til 9 dage efter imprimatur (Om den Clausenske Injuriesag I dag og Politiske Betragtninger og Den danske Statskirke 9 dage).

Hvis man nu beregner 5 uger til indbinding af SB III, har sætning og trykning varet 4 måneder ( I5. 2. til I5.6.). Det vilde da være usand- 
synligt, om de 2 tredjedele af bogen skulde være sat i løbet af den første af disse måneder og kun de 2 I 2 sider i de resterende 3. Forholdsmæssigt beregnet vilde højst de I I ark være sat d. I5. 3., d. v. s. til s. I76, lidt ind i den 8. prædiken (Sexagesima). Først på s. 250 begynder påskeprædikenerne. Skærtorsdag faldt 31.3. Der er intet i vejen for, at Grundtvig kan have skrevet sine påskeprædikener netop i påskedagene I831 - hvad da også de indre grunde taler for ( $\min$ bog s. 79).

Censor har haft hele Nordens Mythologi og Verdenshistorien til gennemsyn (henholdsvis 40 og 42 ark) - hvad enten han nu har læst dem eller ikke. Men læser han overhovedet prædikener? Toldberg formoder selv, at SB I har fået imprimatur alene på grundlag af forordet (s. I5 note I0)! Det er dateret 30.9., og censurdatoen er I. I0. (forordet er skrevet efter prædikenerne). De to næste binds censurdatoer ser noget tilfældige ud: i tilfældet SB II gik der $2^{1} / 2$ måned mellem imprimatur og udgivelse. Når Toldberg mener, at censor måtte passe voldsomt på Grundtvig, fordi forgængeren Eberlin var kommet galt af sted med 3 . stk. af »Om Religions-Frihed « (der blev undertrykt efter at være blevet godkendt af censor) - så forholdt det sig dog vel anderledes med prædikener, hvad de tre censurdatoer da også tyder på. Der behøver ikke at være afleveret ret mange d. 16. 3. 1831. De første bind har jo da også vist, af hvad art de var (i SB III afløste Holm Eberlin).

Hvor langt kan man nu i øvrigt komme med datering af prædikenerne i SB III? Toldberg mener at kunne føre sin første gruppe (A nr. I-5, se s. I8) tilbage til dec. I828-jan. I829, men anfører intet bevis derfor. Kun et oversigtsblad med en prædikenplan synes på grund af vandmærket at være fra 1828 (s. I 7). Udkastene til de tre første prædikener har vandmærket $\mathrm{C} \& \mathrm{~J}$ Honig, der er næsten enerådende i prædikenerne fra slutningen af 1828 til midt i 1833 . Det siger altså intet om den nærmere datering. Men da de er skrevet med gåsepen, må de være fra før 26. I I. I83o. Det er det eneste, man kan sige. Nr. 7 og 8 er skrevet efter denne dato (stålpen). Måske er de tre første tidlige (tidligst slutningen af 1828), men det særlige slagord, som iflg. Toldberg forbinder de 5 første prædikener (»kirkefarvet Hedenskab《), findes kun i nr. 4 og 5 ! Så der er intet, der forhindrer, at de kan være fra tiden efter 2. Englandsrejse, hvad indholdet for mig tyder på de $\operatorname{er}^{1}$ ).

1) Der er intet, der tyder imod, at Grundtvig har skrevet sine prædikener til SB III i den for os foreliggende rækkefølge. Det stemmer også bedst med det sindigt fremadskridende $\mathrm{i}$ hans arbejdsmåde. Lægnummereringen $\mathrm{i}$ de bevarede udkast støtter også antagelsen. Når der i et udkast mangler num- 
Der er heller ikke noget hold i Toldbergs grunde for tidlig datering af en række andre prædikener, f. e. påskeprædikenen, bl. a. med den begrundelse, at udvandringstanken skulde knytte den til I829: Med »pors og lyng « må Grundtvig mene England (siger Toldberg), da han ikke kan vente sig andre trosvilkår, selvom han rejser til Jyllands hede. Men selvfølgelig er det de stærke jyders påskesang (Kingo), han drages imod (jfr. SB III s. 295 f). Der er ikke eet argument tilbage mod de 3 prædikeners affattelse i påsken I83 I, så der er ingen grund til at aflive ideen herom »som en myte« (s.'20).

Jeg lægger dog ingen særlig vægt på den. Derimod afhænger min tolkning af prædikenerne $\mathrm{nr} .5 \mathrm{ff}$ af, at de er skrevet efter den 2. Englandsrejse (ligegyldigt hvornår). Hvad nr. 9 angår (»Christi Nedfart til Helvede«), er der heller ikke noget bevis for, at den er skrevet som en direkte følge af Grundtvigs oldkirkelige studier efter I. Englandsrejse. Hvorfor skulde han dog pludselig give sig til at skrive en prædiken om nedfarten - tilmed uden udgangspunkt $i$ den plan for de tre bind, som han udkastede i 1828 (s. I 7), hvor der ikke er foreslået en sådan fastelavnsprædiken! I I83 I kan derimod de ældre studier udmærket være kommet ham til nytte. Det opdukkende opgør med de lutherske fædre i denne prædiken passer netop godt til tiden efter 3. stk. af »Skal den Lutherske Reformation virkelig fortsættes? « Og Toldbergs tese om »kurven« i Grundtvigs teologiske udvikling, der udelukkende bliver nødvendig på grund af denne kunstige datering af nedfartsprædikenen, kan godt lægges til side: »hans lutherdom er blevet svækket under studierne i I 829, men styrket i I831 «. Det er jo netop nu i I831, Grundtvig begynder for alvor at indtage en selvstændig stilling over for Luther.

- Lige så uholdbar Toldbergs argumentation i den første del af hans udvidede opposition forekommer at være, lige så interessant er den sidste del. Grundtvigs udskrifter af Byrons poesi efter mødet med Mrs. Bolton har jeg overset (Miss Bowring kan roligt lades ude af betragtning som inspirationskilde). Men jeg tror gerne, at de to også har drøftet den netop i Grækenland afdøde digter, som i høj grad var medvirkende til Grækenlandsdyrkelsen i Londons litterære kredse.

Endelig understøtter Toldbergs beskrivelse af Grundtvigs stilling til

merering (s. 16), behøver det slet ikke at betyde, at den tidligere prædiken »endnu ikke er lavet eller i det mindste er ufuldført«. Som registrator ved jeg, at Grundtvig undertiden først satte nummereringen til efter at have skrevet en hel række læg, og at den derfor kunde udeblive, hvis udkastet blev opgivet. 
den hjemlige litterære situation mit eget indtryk af, at Grundtvig før afklaringen ud fra et personligt behov ønskede videnskabeligt samarbejde med anderledes troende (Molbech, H. C. Ørsted, Oehlenschläger). Men først i 1832 gik det op for ham, at det netop principielt var muligt ud fra adskillelsen mellem anskuelse og tro. Men karakteristisk er det hvad Toldberg ikke har tænkt på - at den forsoning med kirkemanden Mynster, som også var hans ønske i foråret I $_{3}$ I (s. 28), netop blev opgivet efter afklaringen. Først nu opdagede Grundtvig, hvor meget der her skilte.

Toldberg har i Danske Studier 1965 behandlet min bog ud fra et litterært synspunkt. Til den meget positive anmeldelse har jeg kun få bemærkninger, men finder det naturligt at føje dem til det foregående. Desværre kan vi ikke mere drøfte tingene igennem.

Toldberg anker over, at jeg i for ringe grad har taget hensyn til overensstemmelse med tidligere forskere og nævner eksempler derpå, først Hal Koch. Dertil vil jeg gerne sige, at Kochs selvstændige forskning vedrører den tidlige Grundtvig (som jeg håber at komme tilbage til, hvorved der bliver rig lejlighed til at tage stilling til en lang række bøger). I sin bog fra I943 er Koch i øvrigt stærkt afhængig af Anders Nørgaard - også i den tolkning af strofen fra »Danne-Virke«, der med hensyn til forholdet mellem danskhed og kristendom udvisker omslaget i Grundtvigs syn efter 1832 (Koch s. I69 f, jfr. Nørgaard I s. 268).

Ligeledes savner Toldberg henvisning til Emil Frederiksens og Niels Kofoeds behandling af Grundtvigs dagbogsoptegnelse af 6.5. 1806, ja, egentlig burde jeg være blevet stående ved deres opfattelse! Nu har jeg selvfølgelig ikke i min meget kortfattede indledning (Grundtvig forfra til I830 på 50 sider!) kunnet gå ind på andre forskeres anskuelser, men har måttet nøjes med (foreløbig) at postulere mit eget syn på udviklingen og også på betydningen af optegnelsen af 6.5. I8o6. Og da jeg netop er uenig med Kofoed, har jeg måttet udskyde min kritik af hans syn til senere. - Fra Uffe Hansen har jeg mærkeligt nok ikke kunnet hente noget, skønt vi, som Toldberg gør opmærksom på det, begge går kronologisk frem, og skønt jeg her kunde være blevet gjort opmærksom på »Det kimer nu til Julefest«! Da den imidlertid ikke er en original Grundtvigsalme, skulde den ikke med i min sammenhæng. - Jeg tror derfor ikke selv, at jeg burde have givet flere litteraturhenvisninger.

Heller ikke en henvisning til et af Toldbergs egne fund var nødvendig. Det drejer sig om Grundtvigs syn på hedningemissionen. Jeg omtaler det ganske kort (s. 612), men Toldberg mener at finde en vis nølen i 
min omtale af Grundtvigs forhold til vennernes missionssyn i 1837 , men har misforstået stedet, idet han tror, at vennerne (i Det danske Missions-Selskab) deler Grundtvigs tidligere syn. Men de er netop enige med ham, og jeg siger udtrykkelig, at de på et møde har hævdet de grundtvigske synspunkter. Der var altså ingen grund for mig til at hente nærmere dokumentation for Grundtvigs syn (hos Wade, Gr.St. I 948 s. 49 ff).

Toldberg mener uden tvivl med rette, at Grundtvigs sans for nygræsk er vågnet gennem Fengers Grækenlandsrejse (jeg gør selv opmærksom på denne mulighed s. 20I). Men da rejsen først fandt sted i i 83 I, er Grundtvigs græeske inspiration tidligere end hans nygræske. Apropos den græske inspiration støtter Toldberg min Bolton-teori med en udmærket henvisning til Saxo (som jeg selv burde have tyet til). Grundtvigs ord om, at han skar sig $\mathrm{i}$ hånden, da han tog på sit sværd (i min bog mener jeg, at de refererer sig til samtalen med Mrs. Bolton, s. 216), sætter Toldberg i forbindelse med Amlets utålmodighed efter hævn under gildet ved hans hjemkomst fra England (Saxooversættelsen I s. I76f): »Alt som han gik, trak han Sværdet ud der hængde ved [bæltet], og prøvede det på Neglene, saa skar han sig i Fingrene«. - Toldberg tilføjer: »Der er endda en engelsk kongedatter der venter på Amlet! «

Et ejendommeligt syn på Grundtvigs indre konflikt udtrykker Toldberg gennem sin påstand om, at hans bundethed til det kristne livssyn fra 18 I5 »afbalanceres« af en stærk filologisk drift, og han slutter herudfra: »Thanings formodning om anden eksistentiel tilskyndelse til Englandsrejserne (s. 226 f) må afvises som grundløs«. Jeg tror imidlertid, at Grundtvigs filologiske drift $\mathrm{i}$ høj grad hang sammen med hans personligste problem - hvad der netop også, måske mod Toldbergs hensigt, kommer frem i ordet »afbalanceres«: der er virkelig her kræfter, der arbejder imod hinanden. Hvad meningen med Englandsbesøget angår, er det værd at bemærke, at Grundtvig i sin ansøgning til kongen om stipendium taler om den filologiske undersøgelses vigtighed »til Oplysning om Menneskelivets Vilkaar, som til en viis og værdig Fortsættelse af Folkelivet« (Br. II s. I45). Her er filologien da sat ind i en værdig sammenhæng! Det var ikke som ensidig filolog Grundtvig drog til England.

Toldberg giver sit bidrag til mellemværendet mellem W. Michelsen og mig ved at hævde, at jeg slet ikke går ind på Michelsens hovedargument: at Grundtvig i fortalen til HV slår til lyd for Carions verdenshistorie fra det I6. årh. Men Michelsen ved godt selv (I s. 40), at Ca- 
rion og hans 4 monarkier var grundlaget for Grundtvigs historieundervisning allerede for 18 ı 0 , så det altså ikke er noget vidnesbyrd om det nye kristne historiesyn, der bryder frem med Grundtvigs lutherske omvendelse. Strukturen hos Carion kan Grundtvig da også anvende efter I832, uden at det strider mod det nye historiesyn - hvorudfra han da også udmærket $\mathrm{i}$ det hele taget kan bruge Bibelen som en historisk grundkilde.

Til slut mit efter Toldbergs mening meget ringe salmekapitel! Det synes, som om han på grund af sin levende optagethed af billedsproget i sig selv ikke har kunnet få øje på, hvor stor betydning Grundtvigs egen definition af en salme ( $\min$ bog s. 56o) har for vurderingen af hans salmes grundpræg og forkyndelse før og efter i 832. Under Toldbergs opposition spurgte han mig, hvad forskellen var på »Velkommen igen« og »Venner! sagde Guds engel blidt«, men min påvisning af det henholdsvis fremadvendte og det nutidige $\mathrm{i}$ de to salmer syntes ikke at gøre noget indtryk på ham. Det er imidlertid alene Grundtvigs livssyn og forkyndelse, der har været mit emne (også når jeg har behandlet billedsprogets frigørelse - s. $439 \mathrm{ff}$ ), og ikke billedsprogets »magt« i salmen. Spørgsmålet om kontinuitet på dette punkt er jeg altså ikke kommet ind på. Over for Toldbergs kritik vil jeg dog anføre - som bevis på, at jeg er opmærksom på problemet - at jeg parentetisk har prist poesien i prologen til »Paaske-Lilien« I8I 7 (som i »De levendes Land « og »Velkommen igen《 I824 s. 57I): »... i I8I7 driver den indre spænding Grundtvig frem til et af hans dejligste digte« (s. 24). Og når Toldberg hævder, at jeg er veget tilbage for at »fastslå kontinuiteten i selve billedsproget fra prædikenerne i Søndags-Bogen III « - så vil jeg gerne igen citere mig selv (s. 6o5 f) : »Bogstavelig talt ligger mange af Grundtvigs kommende salmer ham på læben i Søndagsbogen med dens højtsvungne, poetiske stil - hvorefter jeg som eksempel nævnes 5 salmer med henvisning til sidetal i SB.

- Skulde jeg i forordet til min bog særlig have fremhævet en af de »kolleger inden for Grundtvig-Selskabet«, som det har givet udbytte at diskutere med, vilde jeg have nævnt Helge Toldberg. For mig som teolog var det til stor inspiration at møde en filolog med et så grundfæstet kendskab til Grundtvigs trykte og utrykte forfatterskab, som han kom til fra en helt anden kant end jeg selv. Det fremgår da også af mange henvisninger i min bog, at jeg har haft megen glæde af at læse hans disputats, som jeg ganske vist vilde have ønsket var skrevet på en 
helt anden måde: som en håndbog over Grundtvigs symboler med kronologisk fremadskridende gennemgang af de enkelte symbolers forekomst og betydning.

Vi havde heldigvis - et par måneder før hans død - lejlighed til i hans hjem at drøfte min note om hans grundsyn (s. $462 \mathrm{f}$ ). Her skriver jeg, at $\mathrm{i}$ hans kapitel om Fønikssymbolet bryder hans grundsyn (kontinuiteten i Grundtvigs symbolsyn fra I8I5) åbenlyst sammen. Da jeg forklarede denne (alt for korte) passus for ham, idet jeg erklærede mig fuldstændig enig med ham i dette kapitel, gik der et lys op for ham - og han slog en høj latter op. Denne hjertelige og for Toldberg så karakteristiske latter er mit sidste personlige minde om ham. Men den accept af hovedtesen $\mathrm{i}$ min bog, der foreligger $\mathrm{i}$ hans to anmeldelser, vil jeg se på som en glædelig bekræftelse på, at når to så forskellige par øjne ser på den samme sag og får det samme ud af det - så kan det, vi er enige om, ikke være helt forkert.

NB. På grund af pladsmangel har jeg ikke her kunnet svare Pontoppidan Thyssen (Kirkehistoriske Samlinger) og Regin Prenter (Dansk teologisk Tidsskrift). Det må så ske på anden måde. 